\title{
In Situ Quantification of Reaction Adsorbates in Low-Temperature Methanol Synthesis on a High-Performance Cu/ZnO:Al Catalyst
}

\author{
Andrey V. Tarasov, ${ }^{*}{ }^{\dagger}$ Friedrich Seitz, ${ }^{\dagger}$ Robert Schlögl, ${ }^{\dagger, \dagger}$ and Elias Frei* ${ }^{* \dagger}$ \\ ${ }^{\dagger}$ Department of Inorganic Chemistry, Fritz-Haber Institut der Max-Plack Gesellschaft, Faradayweg 4-6, 14195 Berlin, Germany \\ ${ }^{\ddagger}$ Department of Heterogeneous Reactions, Max-Planck-Institute for Chemical Energy Conversion, Stiftstrasse 34-36, 45470 \\ Mühlheim an der Ruhr, Germany
}

Supporting Information

ABSTRACT: The industrial low-temperature process has been applied for 50 years; however, in situ data under relevant conditions are rare. We report on the in situ quantification of the surface adsorbates present under industrially relevant conditions by high-pressure thermogravimetry. In addition, high-pressure IR spectroscopy is applied for the identification of carbon-based adsorbates. On a high-performance $\mathrm{Cu}$ / $\mathrm{ZnO}: \mathrm{Al}$ catalyst it has been shown that during $\mathrm{CO}_{2}$ hydrogenation adsorbates of up to 1.9 wt \% of the catalyst are reversibly accumulated, and $70 \%$ of the ad-layer consists of $\mathrm{H}_{2} \mathrm{O}$-derived species. Under CO-hydrogenation conditions, the weight accumulation on the surface is limited to an increase of $1.2 \mathrm{wt} \%$ mainly due to the absence of $\mathrm{H}_{2} \mathrm{O}$. The stable adsorbate layers from different feeds are qualitatively assigned by surface titration experiments and spectroscopic insights. In accordance with the literature, it is clearly illustrated that, on the basis of the feed-dependent coverage of the surface, different reaction mechanisms for the methanol formation are involved. These

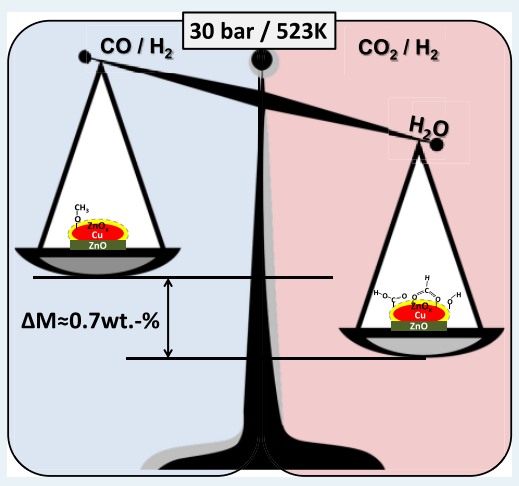
investigations under realistic conditions finally show the importance of $\mathrm{Zn}-\mathrm{OH}$ groups, likely located at the $\mathrm{Cu} / \mathrm{ZnO}$ interface, as being crucial for activation and hydrogenation of $\mathrm{CO}_{2}$-derived intermediates to $\mathrm{CH}_{3} \mathrm{OH}$. The accumulation of $\mathrm{H}_{2} \mathrm{O}$ - and carbon-derived species on the surface of the catalyst might explain the poor activity in $\mathrm{CH}_{3} \mathrm{OH}$ formation at low temperatures and consequently limits the application of $\mathrm{Cu} / \mathrm{ZnO}$-based catalysts under mild, thermodynamically preferred conditions.

KEYWORDS: methanol synthesis, surface adsorbates, $\mathrm{Cu} / \mathrm{ZnO}: \mathrm{Al}$ catalyst, high-pressure infrared spectroscopy, high-pressure thermogravimetry

\section{INTRODUCTION}

The conversion of synthesis gas $\left(\mathrm{CO} / \mathrm{CO}_{2} / \mathrm{H}_{2}\right)$ to $\mathrm{CH}_{3} \mathrm{OH}$ is one of the most important industrial processes, in particular with respect to the $\mathrm{CO}_{2}$ emissions as the main cause of climate change. For decades, a $\mathrm{Cu} / \mathrm{ZnO}$-based catalyst has been applied and is still controversially discussed. ${ }^{1}$ The interfacial contact of $\mathrm{Cu} / \mathrm{ZnO}$ is generally accepted as an important site where the synergistic effects (structural and electronic) are focused. ${ }^{2}$ To gain information on relevant intermediates of the $\mathrm{CH}_{3} \mathrm{OH}$ formation, the adsorption of $\mathrm{CO}$ and $\mathrm{CO}_{2}$ on $\mathrm{Cu}$ - and $\mathrm{Cu} / \mathrm{ZnO}$-based catalysts has been intensely studied. ${ }^{3}$ In addition, the experimental reports and numerous theoretical calculations agreed on the presence of carbon- and waterderived surface species. The most abundant species observed are formates, ${ }^{4}$ methoxy, ${ }^{4 \mathrm{~d}, 5}$ carboxyl, ${ }^{3 \mathrm{~b}, 6}$ formyl, ${ }^{4 \mathrm{~b}, 7}$ carbonates, ${ }^{8}$ hydroxyl, ${ }^{8}$ and $\mathrm{H}_{2} \mathrm{O}$ (Scheme S1). These studies, however, are often performed under low surface coverages and conditions far from industrial relevance. In an attempt to bridge the pressure gap, several IR-reactivity studies were performed under elevated pressure up to 6 bar. The results of a transient kinetic analysis ${ }^{60,9}$ made evident the formation of a formate layer, which was found to be unreactive toward methanol and suggested the reaction pathway through an elusive carboxyl intermediate. ${ }^{6}$ Investigations on $\mathrm{Cu} / \mathrm{ZnO}$ model catalysts, in contrast, identified formates as reaction intermediates. $^{2 \mathrm{f}}$

Another intriguing phenomenon observed ${ }^{6 a, b}$ is the ambiguous effect of $\mathrm{H}_{2} \mathrm{O}$ upon $\mathrm{CO} / \mathrm{CO}_{2}$ hydrogenation on the $\mathrm{CH}_{3} \mathrm{OH}$ formation rate. The promotional effect of $\mathrm{H}_{2} \mathrm{O}$ at finite conversions in $1-4 \% \mathrm{CO}_{2}$ has been reported previously. ${ }^{10}$ On the other hand, at integral conditions, product inhibition by water decreases the $\mathrm{CH}_{3} \mathrm{OH}$ rate as shown by Sahibzada et al. ${ }^{10 a}$ Beyond mechanistic considerations, the accumulation and influence of reaction products and intermediates on $\mathrm{Cu} / \mathrm{ZnO}$-based catalysts are of high relevance, since lower reaction temperatures are needed due to the thermodynamic limitations within the $\mathrm{CO}_{2}$-utilization concept. $^{1}$

Herein, we report on probing a $\mathrm{Cu} / \mathrm{ZnO}: \mathrm{Al}$ industrial-like catalyst under $\mathrm{CH}_{3} \mathrm{OH}$ synthesis conditions in $\mathrm{CO}$ - and $\mathrm{CO}_{2}-$ containing feeds. High-pressure in situ thermogravimetry investigations provide quantitative insights into the composition of adsorbed layers. The observed results are qualitatively compared with in situ IR experiments at 30 bar and transient

Received: March 26, 2019

Revised: April 30, 2019

Published: May 8, 2019 
surface reaction/titration experiments. Special attention is given to the role of water-derived species as part of the catalytically formed ad-layer and on possible carbon-based reaction adsorbates stable under reaction conditions. The complementary applied characterization techniques give new insights into the surface composition under industrially relevant conditions, clearly emphasizing the complexity of catalytic surface processes.

\section{QUANTIFICATION OF THE REACTION ADSORBATES}

The in situ thermogravimetric measurement in different feed compositions at $30 \mathrm{bar}$ and $523 \mathrm{~K}$ is shown in Figure 1. The

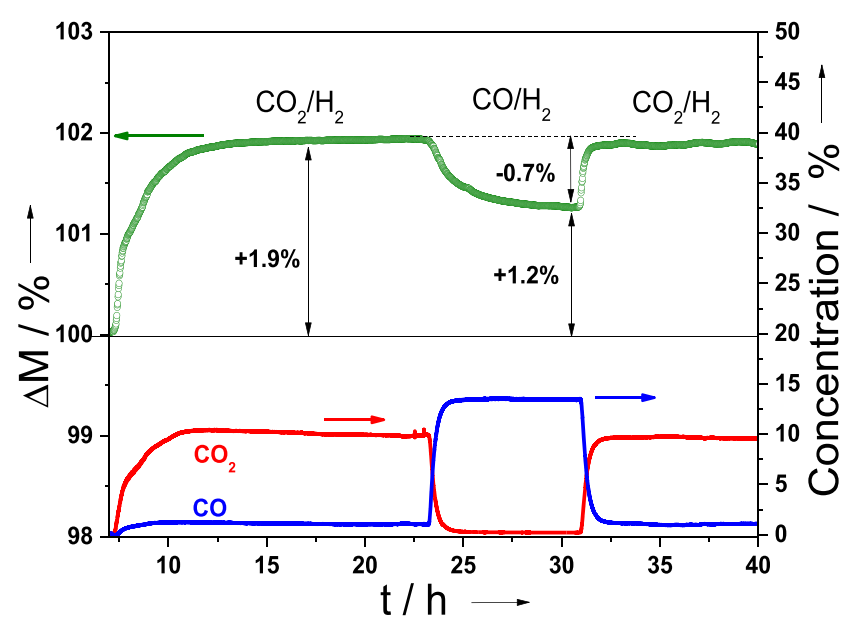

Figure 1. In situ thermogravimetry in different feed gases at $523 \mathrm{~K}$. $\mathrm{CO}_{2} / \mathrm{H}_{2} / \mathrm{He}(12 / 59 / 29), \mathrm{CO} / \mathrm{H}_{2} / \mathrm{Ar} / \mathrm{He}(14 / 59 / 4 / 23), 120 \mathrm{~mL}$ $\mathrm{min}^{-1}$ at $30 \mathrm{bar}$, with online analysis of the gas phase.

correction for the buoyancy force for various gas mixtures is described in the Supporting Information (SI, see also Table S1). After activating the catalyst $\left(20 \% \mathrm{H}_{2}\right.$ in $\left.\mathrm{Ar}\right)$, the gas mixture is switched to a $\mathrm{CO}_{2}$-containing feed. A direct weight increase makes evident the formation of an adsorbate layer on the catalyst surface, reaching a steady-state situation after $\approx 10$ $\mathrm{h}$ under $\mathrm{H}_{2} / \mathrm{CO}_{2}$ feed and a mass gain of $1.9 \mathrm{wt} \%$ of the initial mass. Changing the feed composition to $\mathrm{H}_{2} / \mathrm{CO}$ causes a reversible loss of $0.7 \mathrm{wt} \%$ within a period of $\approx 8 \mathrm{~h}$ (Figure 1 ). One has to consider that the pure support also shows a reversible mass uptake of $0.1-0.2$ wt $\%$ when substituting $\mathrm{H}_{2}$ / $\mathrm{CO}$ by $\mathrm{H}_{2} / \mathrm{CO}_{2}$ (Figures $\mathrm{S} 1$ and $\mathrm{S} 2$ ). This deviation defines the accepted level of tolerance for the mass at steady state.
Based on transient $\mathrm{H}_{2}$ adsorption and $\mathrm{N}_{2} \mathrm{O}$ reactive frontal chromatography techniques, the $\mathrm{Cu}$ sites are given as 400 $\mu \mathrm{mol} \mathrm{g}{ }_{\text {cat }}{ }^{-1}$ and $\mathrm{ZnO}_{x}$ sites as $273 \mu \mathrm{mol} \mathrm{g}_{\text {cat }}{ }^{-1}$ (see also Table 1 and Table S2). The experimental values of the available redox active surface sites are used to calculate a possible mass increase based on the available surface sites. The good agreement between the calculated and experimentally quantified mass gain in the thermobalance also serves as validation of the applied surface and reaction model. To clarify the possible role of $\mathrm{H}_{2} \mathrm{O}$ and $\mathrm{H}_{2} \mathrm{O}$-derived species (e.g., $\mathrm{OH}$ groups), the catalyst was saturated in the thermobalance with a $\mathrm{H}_{2} /$ Ar stream enriched with 1.5 vol $\% \mathrm{H}_{2} \mathrm{O}$ (Figure $2 \mathrm{~A}$ ). After
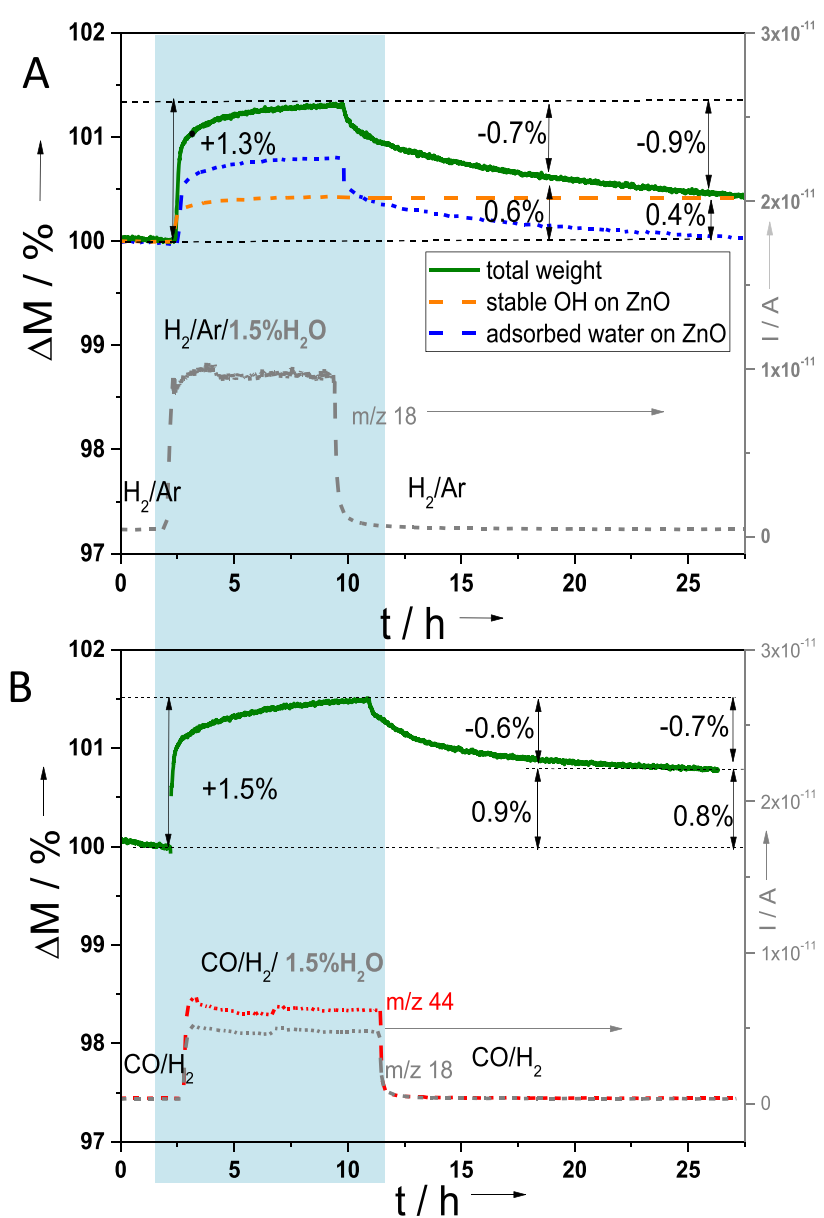

Figure 2. In situ $\mathrm{TG}$ of $\mathrm{Cu} / \mathrm{ZnO}: \mathrm{Al}$ at $1 \mathrm{bar}, 523 \mathrm{~K}$. Introduction of 1.5 vol \% $\mathrm{H}_{2} \mathrm{O}$ vapor to (A) $85 \% \mathrm{H}_{2} / \mathrm{Ar}$ feed (dotted lines visualize the adsorbed $\mathrm{H}_{2} \mathrm{O}$-derived species on $\mathrm{ZnO}_{x}$ ) and (B) $14 \% \mathrm{CO} / 59 \%$ $\mathrm{H}_{2} / 27 \%$ inert.

Table 1. Theoretical Mass Increase of the Catalyst under the Assumption of a Surface Fully Covered with One Type of Species $^{a}$

$\begin{array}{lcccc}\text { group } / M{ }^{b} \text { g mol }^{-1} & \text { surface stoichiometry } & \Delta M^{c} \%(\mathrm{Cu} \text { sites }) & \Delta M^{d} \%(\mathrm{ZnO} \text { sites }) & 0.49 \\ \mathrm{H}_{2} \mathrm{O} / 18 \text { water } & 1 & 0.72 & 0.46 \\ \mathrm{OH} / 17 \text { hydroxy } & 1 & 0.68 & 0.85 \\ \mathrm{OCH}_{3} / 31 \text { methoxy } & 1 & 1.24 & 0.79 \\ \mathrm{CHO} / 29 \text { formyl } & 1 & 1.16 & 1.14 \\ \mathrm{CHOO} / 45 \text { formate } & 2 / 1 & 1.8 / 0.9 & 1.2 / 0.6\end{array}$

${ }^{a}$ Percent of the initial catalyst loading indicated. ${ }^{b}$ Proposed stable surface species present on the surface ${ }^{13}{ }^{c}$ Calculation performed using the number of $\mathrm{Cu}$ sites of $400 \mu \mathrm{mol}(\mathrm{Cu}) \mathrm{g}_{\text {cat }}{ }^{-1}$ as determined by the $\mathrm{H}_{2}$ transient adsorption technique. ${ }^{14} d$ The amount of oxygen vacancies of layered $\mathrm{ZnO}_{x}{ }^{15}$ was measured as the difference of the values obtained from $\mathrm{N}_{2} \mathrm{O}$ RFC and $\mathrm{H}_{2}$ TA as suggested by Schumann et al., ${ }^{14 a}$ and assessed as 273 $\mu \mathrm{mol}\left(\mathrm{ZnO}_{x}\right) \mathrm{g}_{\text {cat }}{ }^{-1}$. Calculations are shown in the SI. 
ca. $10 \mathrm{~h}$ time-on-stream (TOS), a stable mass increase of 1.3 wt $\%$ was reached. Switching to $\mathrm{H}_{2} /$ Ar leads to a mass decrease of 0.7 wt $\%$ within $\approx 8 \mathrm{~h}$ which continued to decrease slowly. An identical experiment was conducted with $\mathrm{H}_{2} / \mathrm{CO}$ enriched using $1.5 \mathrm{vol} \% \mathrm{H}_{2} \mathrm{O}$. After stabilizing at a mass increase of 1.5 wt \%, a mass loss of 0.6 wt \% is observed upon switching to $\mathrm{H}_{2} / \mathrm{CO}$ again (Figure 2B). The experiments of switching the gas feed $\left(\mathrm{H}_{2} / \mathrm{CO}_{2}\right.$ and $\left.\mathrm{H}_{2} / \mathrm{CO}\right)$ and $\mathrm{H}_{2} /$ Ar enriched with $1.5 \%$ $\mathrm{H}_{2} \mathrm{O}$ were repeated with a $\mathrm{Cu} / \mathrm{MgO}$ reference catalyst (Figure $\mathrm{S} 3 \mathrm{~A}, \mathrm{~B})$. This catalyst exposes an almost identical $\mathrm{Cu}$ nanostructure (compared to $\mathrm{Cu} / \mathrm{ZnO}: \mathrm{Al}$, see Table $\mathrm{S} 2$ ), but the mass uptake in the $\mathrm{H}_{2} \mathrm{O}$-containing feed seems to be negligible (Figure S3B). This makes evident that the mass increase under $\mathrm{H}_{2} \mathrm{O}$ atmosphere directly correlates with the presence of $\mathrm{ZnO}$. These findings are already incorporated into Figure $2 \mathrm{~A}$, where the mass increase is separated into two contributions from $\mathrm{ZnO}$, adsorbed $\mathrm{H}_{2} \mathrm{O}$ and strongly bound $\mathrm{OH}$ groups. The weight increase due to the stable $\mathrm{OH}$ groups (0.4-0.6 wt \%) correlates very well with the calculated values based on oxygen vacancies in $\mathrm{ZnO}_{x}$ (Table 1 and Table S2, 0.5 wt $\%)$ and supports our findings. To investigate the possible impact of $p\left(\mathrm{H}_{2} \mathrm{O}\right)$ on the mass gain, a series of experiments with different $\mathrm{H}_{2} \mathrm{O}$ concentrations in $\mathrm{H}_{2} / \mathrm{Ar}$ (up to 2.0 vol \%) were conducted (Figure S4). Already at comparably low $\mathrm{H}_{2} \mathrm{O}$ concentrations ( $0.5 \mathrm{vol} \%)$, the mass uptake levels off, and a saturation regime is reached. This implies that the experiments described in Figure 2 already reached steady state. In addition, the gained information from the TG curves in Figure $2 \mathrm{~A}, \mathrm{~B}$ makes evident that, in Figure 1, when switching between $\mathrm{H}_{2}$ / $\mathrm{CO}_{2}$ and $\mathrm{H}_{2} / \mathrm{CO}$, the mass loss is also due to the removal of $\mathrm{H}_{2} \mathrm{O}$-derived species. As a consequence, the maximum amount of strongly bound $\mathrm{OH}$ groups still present on the $\mathrm{ZnO}_{x}$ surface ranges from 0.4 to $0.8 \mathrm{wt} \%$ of the catalyst, again in agreement with our reference experiments (Figure 2A,B, Figure S3, and Table 1). Further, it is very likely that, depending on the gas feed used, carbon-based reaction intermediates are also present. This is supported by the residual mass after switching from $\mathrm{H}_{2} / \mathrm{CO}_{2}$ to $\mathrm{H}_{2} / \mathrm{CO}$ (Figure 1A, stable ad-layer of $1.2 \mathrm{wt}$ $\%)$; at least $0.4-0.8$ wt $\%$ consists of non- $\mathrm{H}_{2} \mathrm{O}$-related adsorbates, namely, carbon-based derivatives (dependent on the stable $\mathrm{OH}$ group concentration). The majority of the carbon-derived adsorbates might be placed on the $\mathrm{Cu}$ moieties, also in agreement with $\mathrm{Cu} / \mathrm{MgO}$ reference experiments (Figure S3A).

Figure 3 illustrates the deconvolution of experimental mass changes in different reaction feeds $\left(\mathrm{H}_{2} / \mathrm{CO}_{2}\right.$ or $\left.\mathrm{CO}\right)$ to $\mathrm{H}_{2} \mathrm{O}$ derived and carbon-derived. ${ }^{11}$ Approximately $70 \%$ of the adlayer consists of $\mathrm{H}_{2} \mathrm{O}$-derived species. The amount of carbonbased intermediates is interpreted as stable upon switching to the $\mathrm{H}_{2} / \mathrm{CO}$ feed. This 0.6 wt $\%$ (or $\sim 30 \%$ of the ad-layer) does, very likely, not consist of similar adsorbates, since different mechanisms (and intermediates) are discussed for the hydrogenation of $\mathrm{CO}$ and $\mathrm{CO}_{2} \cdot{ }^{3 a, 6 a, b, 12}$ However, it is expected that the $\mathrm{CO}_{2}$-related ad-layer is very stable, which hinders its activation in the $\mathrm{CO} / \mathrm{H}_{2}$ feed after consecutive switching, and the exchange might be slow. ${ }^{3 a}$ Consistent with a previous spectroscopic analysis, ${ }^{13}$ the remaining layer may comprise -methoxy $\left(-\mathrm{OCH}_{3}\right)$, -formyl $(-\mathrm{CHO})$, and/or -formate $\left(-\mathrm{O}_{2} \mathrm{CH}\right)$ species balanced with $\mathrm{OH}$ groups, in very good agreement with the mass changes and resulting quantitative assessments from our thermogravimetric experiments (Table 1).

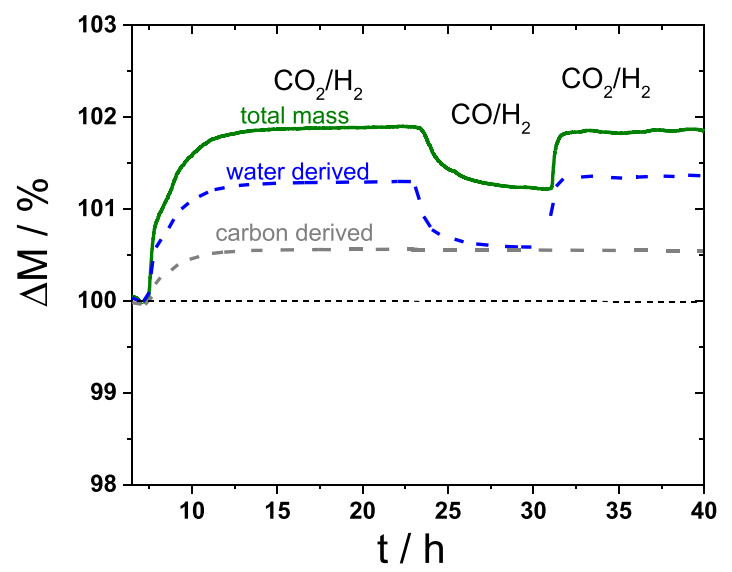

Figure 3. In situ thermogravimetry with different gas feeds $\left[\mathrm{CO}_{2} / \mathrm{H}_{2} /\right.$ $\mathrm{He}(12 / 59 / 29)$ and $\left.\mathrm{CO} / \mathrm{H}_{2} / \mathrm{Ar} / \mathrm{He}(14 / 59 / 4 / 23), 120 \mathrm{~mL} \mathrm{~min}^{-1}\right]$ at $523 \mathrm{~K}$ and 30 bar. Dotted lines visualize the possible mass change associated with $\mathrm{H}_{2} \mathrm{O}$ - and carbon-derived species.

\section{NATURE OF THE CARBON-BASED ADSORBATES}

To further clarify the nature of the intermediates adsorbed during catalysis, high-pressure IR experiments were conducted under reaction conditions ( $30 \mathrm{bar}, 523 \mathrm{~K}$ ) in a cell as already described. ${ }^{16}$ To overcome the high noise level caused by the low IR transparency of the catalyst, four spectra with 2048 scans each were averaged for the data evaluation.

The spectra are dominated by the gas phase signals of the applied feeds, namely, $\mathrm{CO}$ and/or $\mathrm{CO}_{2}$ and the corresponding overtones (Figure 4A). With the onset of the reaction, bands due to the reaction product $\mathrm{CH}_{3} \mathrm{OH}\left(2960\right.$ and $\left.1033 \mathrm{~cm}^{-1}\right)$ become visible and directly make evident the active state of the catalyst within the spectrometer. In addition to this, in the $\mathrm{H}_{2}$ / $\mathrm{CO}_{2}$ feed, the rotovibrational bands of the rWGS reaction products $\mathrm{H}_{2} \mathrm{O}$ (centered at 3780 and $1600 \mathrm{~cm}^{-1}$ ) and $\mathrm{CO}$ (centered at $2143 \mathrm{~cm}^{-1}$ ) occur. The $\mathrm{H}_{2} \mathrm{O}$ signals are strongly decreased under $\mathrm{H}_{2} / \mathrm{CO}$ conditions, since $\mathrm{CO}$ reacts instantly with traces of $\mathrm{H}_{2} \mathrm{O}$ under the formation of $\mathrm{CO}_{2}$ (Figure 4A, WGS reaction).

Only after correcting for the gas phase products, a meaningful interpretation of surface adsorbates is possible (Figure 4B). In the $\mathrm{H}_{2} / \mathrm{CO}_{2}$ feed, a broad feature with a maximum at $2890 \mathrm{~cm}^{-1}$ and a weaker one at $\sim 2600 \mathrm{~cm}^{-1}$ are assigned to $\mathrm{C}-\mathrm{H}$ stretching vibrations and are distinctly different from the $\mathrm{CH}_{3} \mathrm{OH}$ band at $2950 \mathrm{~cm}^{-1}$. The clearly visible bands around 1520 and $1390 \mathrm{~cm}^{-1}$ are similar to assignments of formate species. ${ }^{17}$ The mode around 1520 $\mathrm{cm}^{-1}$ corresponds either to formate on the $\mathrm{ZnO}: \mathrm{Al}$ support (or at the interface to $\mathrm{Cu}$ ) or to its asymmetric stretch vibration on Cu. ${ }^{17 a}$ The band at $1390 \mathrm{~cm}^{-1}$ is assigned to the symmetric vibration of bidentate formate on $\mathrm{Cu}$. These findings agree well with the bidentate formate $\mathrm{C}-\mathrm{H}$ modes at $2890 \mathrm{~cm}^{-1}$. The signal at the $2600 \mathrm{~cm}^{-1}$ band is typical for $\mathrm{C}-\mathrm{H}$ stretching modes of formyl species, which is supported by the $\mathrm{C}=\mathrm{O}$ stretching vibration at $1760 \mathrm{~cm}^{-1} .{ }^{18}$ The shoulder to higher wavenumbers at $2950 \mathrm{~cm}^{-1}$ might be related to methoxy groups. ${ }^{13}$ Since the IR bands are rather broad, other carbonbased intermediates like carboxylates cannot be ruled out. The presence of surface $\mathrm{O}-\mathrm{H}$ groups is evident from IR absorption features around $3500-3700 \mathrm{~cm}^{-1}$ partly obscured by the $\mathrm{CO}_{2}$ overtones and supported by thermogravimetric measurements. 


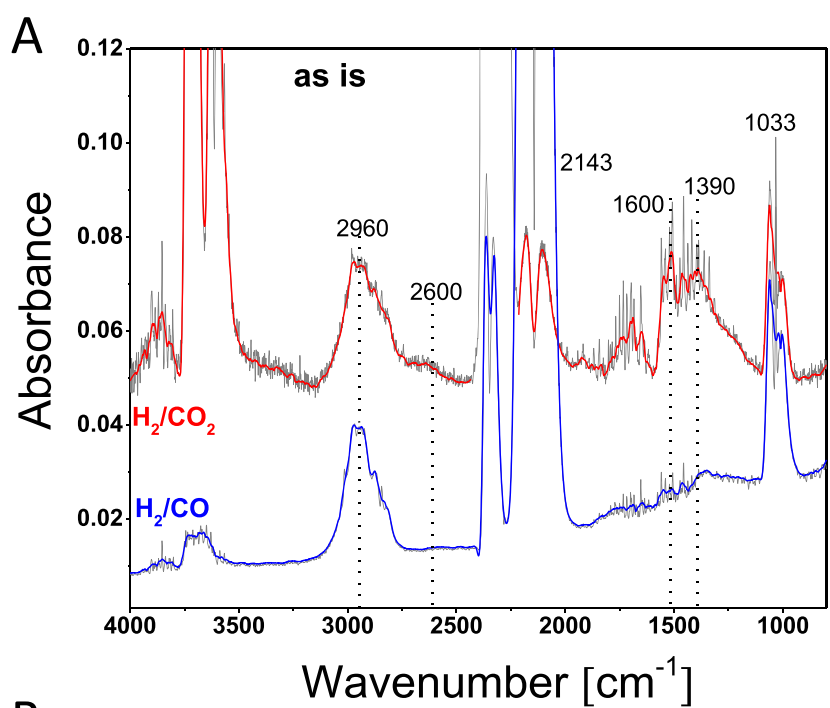

B

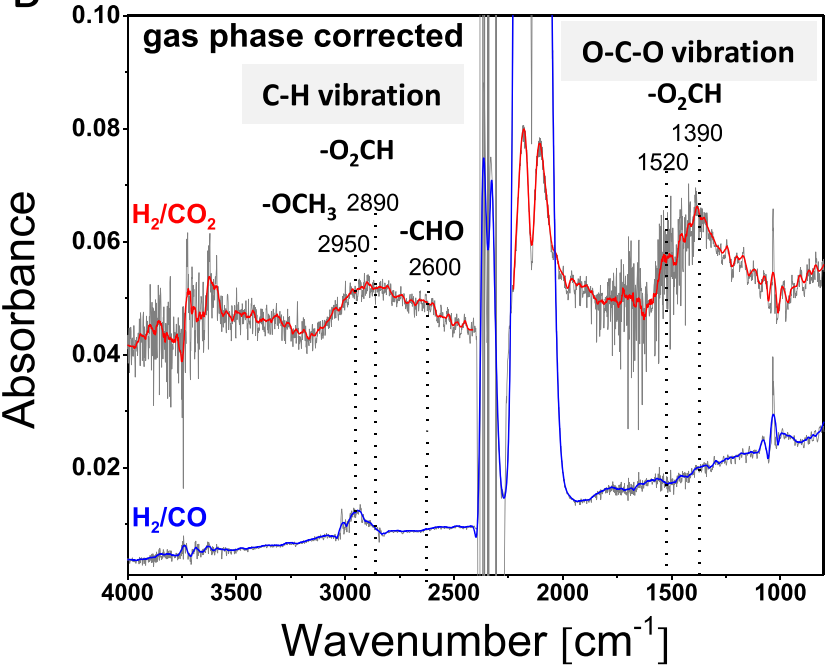

Figure 4. In situ IR spectroscopy at 30 bar and $523 \mathrm{~K}$ : (A) $\mathrm{H}_{2} / \mathrm{CO}_{2}$ feed and $\mathrm{H}_{2} / \mathrm{CO}$ feed and (B) with gas phase correction. The colored lines represent the smoothed spectra.

Thus, the results of high-pressure in situ IR spectroscopy in the $\mathrm{H}_{2} / \mathrm{CO}_{2}$ feed confirm the presence of surface formate groups on $\mathrm{Cu}$ (bands at 2890 and $1390 \mathrm{~cm}^{-1}$ ), possibly on $\mathrm{ZnO}: \mathrm{Al}$ or the interface to $\mathrm{Cu}\left(1520 \mathrm{~cm}^{-1}\right)$, methoxy groups $\left(2950 \mathrm{~cm}^{-1}\right)$, and surface hydroxyl groups $\left(\sim 3500 \mathrm{~cm}^{-1}\right)$. Carbonates are ruled out since $\mathrm{CO}_{2}$ does not adsorb at 483K/ $523 \mathrm{~K}$ and 30 bar pressure (Figure S5B). These findings agree well with the interpretation of the thermogravimetry experiments discussed above, identifying $\mathrm{H}_{2} \mathrm{O}$ - and carbon-derived adsorbates on the surface (Figures 1 and 3 and Table 1). The presence of methoxy groups is further supported by the gas phase corrected spectra from the $\mathrm{H}_{2} / \mathrm{CO}$ feed (Figure 4B). The pronounced signal at $2950 \mathrm{~cm}^{-1}$ is clearly identified as the $\mathrm{C}-\mathrm{H}$ stretch vibration of the methoxy group, with small contributions of the $\mathrm{C}-\mathrm{O}$ stretching or bending modes at $1020 \mathrm{~cm}^{-1}$ and not part of the gas phase $\mathrm{CH}_{3} \mathrm{OH}$ signals. In addition, no formate contributions are detected. Changes in the range of $3500 \mathrm{~cm}^{-1}$ due to additional $\mathrm{OH}$ groups (i.e., $\mathrm{Zn}-$ $\mathrm{OH}$ groups, in comparison to the $\mathrm{H}_{2} / \mathrm{Ar}$ reduction mix) are also absent. This means that, under different feed gas compositions $\left(\mathrm{H}_{2} / \mathrm{CO}\right.$ versus $\left.\mathrm{H}_{2} / \mathrm{CO}_{2}\right)$, the nature of the adsorbates is differently pronounced. The intermediate concentration increases with higher temperatures and reaction rates (Figure S6, 523 versus $483 \mathrm{~K}$ ), which is an indication for a surface accumulation. To mimic the switch of the gas feed applied in Figure $1\left(\mathrm{H}_{2} / \mathrm{CO}_{2} \rightarrow \mathrm{H}_{2} / \mathrm{CO} \rightarrow \mathrm{H}_{2} / \mathrm{CO}_{2}\right)$, an adapted transient experiment was conducted in the IR spectrometer (Figure 5A,B). Starting from a $\mathrm{H}_{2} / \mathrm{CO}$ feed
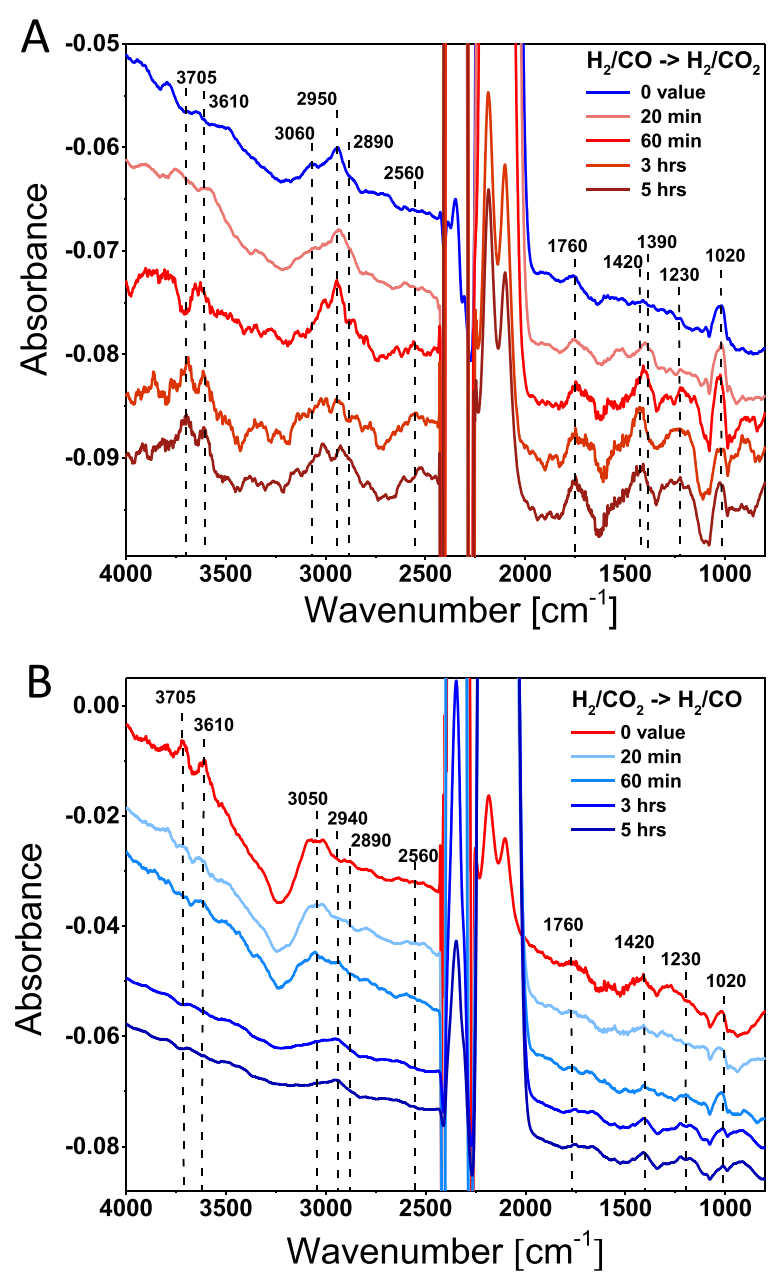

Figure 5. In situ IR spectroscopy at $523 \mathrm{~K}$ and 30 bar, upon switching the gas phase from (A) $\mathrm{H}_{2} / \mathrm{CO}$ (blue) to $\mathrm{H}_{2} / \mathrm{CO}_{2}$ (red) and (B) from $\mathrm{H}_{2} / \mathrm{CO}_{2}$ (red) to $\mathrm{H}_{2} / \mathrm{CO}$ (blue). The curves represent smoothed spectra.

(Figure 5A, blue curve), a change to $\mathrm{H}_{2} / \mathrm{CO}_{2}$ leads also to a change of the adsorbed species (Figure $5 \mathrm{~A}$, red curves). From a methoxy dominated surface $\left(2950 \mathrm{~cm}^{-1}, 1020 \mathrm{~cm}^{-1}\right)$ with contributions from a carboxylate species $\left(3040 \mathrm{~cm}^{-1}, 1760\right.$ $\left.\mathrm{cm}^{-1}, 1230 \mathrm{~cm}^{-1}\right)$, ${ }^{3 \mathrm{~b}}$ formate $\left(2890 \mathrm{~cm}^{-1}, 1390 \mathrm{~cm}^{-1}\right)$ and formyl $\left(2600 \mathrm{~cm}^{-1}\right.$, around $\left.1760 \mathrm{~cm}^{-1}\right)$ species start to grow. As a function of time, the latter become more intense, and the $\mathrm{OH} / \mathrm{H}_{2} \mathrm{O}$ influence is clearly visible between 3500 and 3750 $\mathrm{cm}^{-1}\left(\mathrm{O}-\mathrm{H}\right.$ stretching modes) and $1500-1750 \mathrm{~cm}^{-1}(\mathrm{O}-\mathrm{H}$ bending modes). Likely, the asymmetric modes of formate intermediates contribute to the shoulder at $1520 \mathrm{~cm}^{-1}$ and shift the maximum at $1390 \mathrm{~cm}^{-1}$ (symmetric formate vibration) to higher wavenumbers $\left(1420 \mathrm{~cm}^{-1}\right) .{ }^{9}$ The inverse experiment (Figure 5B) clearly shows that a gas switch from the $\mathrm{H}_{2} / \mathrm{CO}_{2}$ to $\mathrm{H}_{2} / \mathrm{CO}$ feed does not lead to a complete exchange of the carbon-derived species toward methoxy groups but to a removal of the $\mathrm{H}_{2} \mathrm{O}$-derived species (e.g., above 3500 
$\left.\mathrm{cm}^{-1}\right)$. Still, after hours, absorption features of other oxygenates are present. The exchange of surface intermediates triggered by a change of the gas phase seems to be rather a process of hours, ${ }^{19}$ which is in line with the thermogravimetric kinetics and, e.g., the recovering of a $\mathrm{Cu} / \mathrm{MgO}$ catalyst after poisoning with $\mathrm{CO}_{2}$. ${ }^{3 a}$ The formation of, e.g., the $\mathrm{H}_{2} / \mathrm{CO}_{2}$ induced surface intermediates directly after activation seems to be a rather fast process and not resolvable on the minute scale (Figure S5A).

Figure 6 shows additional experiments in the thermobalance, where from the $\mathrm{H}_{2} / \mathrm{CO}$ feed (green curve) the same mass gain

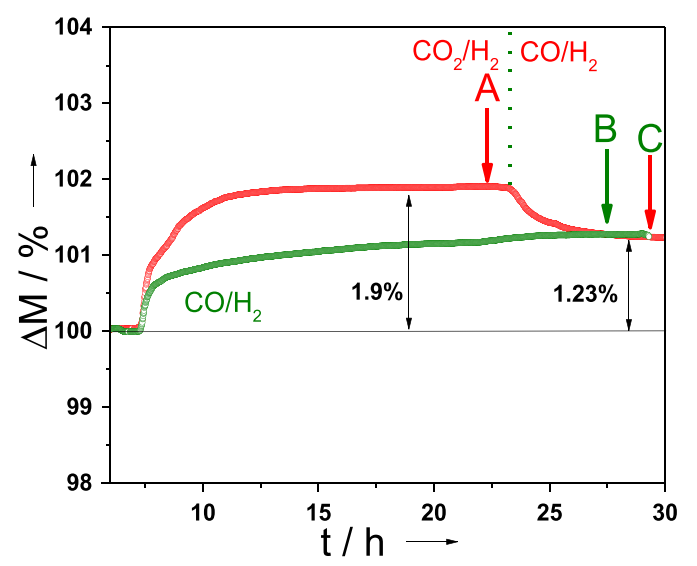

Figure 6. In situ TG experiments at 30 bar and $523 \mathrm{~K}$, exposures starting from $\mathrm{H}_{2} / \mathrm{CO}$ (green) and $\mathrm{H}_{2} / \mathrm{CO}_{2}$ (red). Letters indicate the points where the titration experiments in a fixed bed reactor were performed.

is reached as upon switching to $\mathrm{H}_{2} / \mathrm{CO}$ after introducing $\mathrm{H}_{2} /$ $\mathrm{CO}_{2}$ (red curve). With respect to the assignments made by high-pressure in situ IR experiments, the mass gain in $\mathrm{H}_{2} / \mathrm{CO}$ is interpreted as mainly caused by methoxy groups on $\mathrm{Cu}$ sites, which would allow for a mass increase in the range of $1.24 \%$ according to Table 1 . It is very likely that also $\mathrm{OH}$ groups contribute as a minor fraction to the mass increase and that the $\mathrm{Cu}$ surface is not completely covered since $\mathrm{H}_{2}$ activation has to be possible. ${ }^{20}$ Further, we propose different surface adsorbates in $\mathrm{H}_{2} / \mathrm{CO}$ after $\mathrm{H}_{2} / \mathrm{CO}_{2}$ treatment (Figure 6, state $\mathrm{C}$ ) compared to only the $\mathrm{H}_{2} / \mathrm{CO}$ feed (Figure 6, state B). This means that the accumulated adsorbates, e.g., formyl- and formate groups (Figure 6, state A), are in part substituted by methoxy groups during $\mathrm{H}_{2} / \mathrm{CO}$ treatment at $30 \mathrm{bar}$, also made evident by IR spectroscopy (Figure 5B).

\section{REACTIVITY OF THE SURFACE AD-LAYER}

To probe the stability and difference in origin of the carbonrelated species formed in $\mathrm{H}_{2} / \mathrm{CO}_{2}$ and $\mathrm{H}_{2} / \mathrm{CO}$ feeds, a transient surface titration technique analogous to that reported by Yang et al. ${ }^{6,21}$ was applied. In addition, as shown previously in our purging experiments, ${ }^{3 a}$ a sustained methanol production for several hours was observed when switching from the $\mathrm{CO}_{x} /$ $\mathrm{H}_{2}$ feed gas to $\mathrm{H}_{2} /$ Ar.

Herein, after reaching steady state at 30 bar, the catalysts were purged with $\mathrm{Ar}$ gas until reaching a zero signal (baseline, monitored by online GC). Subsequently, $\mathrm{H}_{2} / \mathrm{Ar}$ mixtures were introduced to mobilize possible surface intermediates. Figure 6 shows the different steady-state points $\mathrm{A}, \mathrm{B}$, and $\mathrm{C}$ for which the investigations were performed. The experimental results are shown in Figure 7, also named as A, B, and C. In Figure 7A

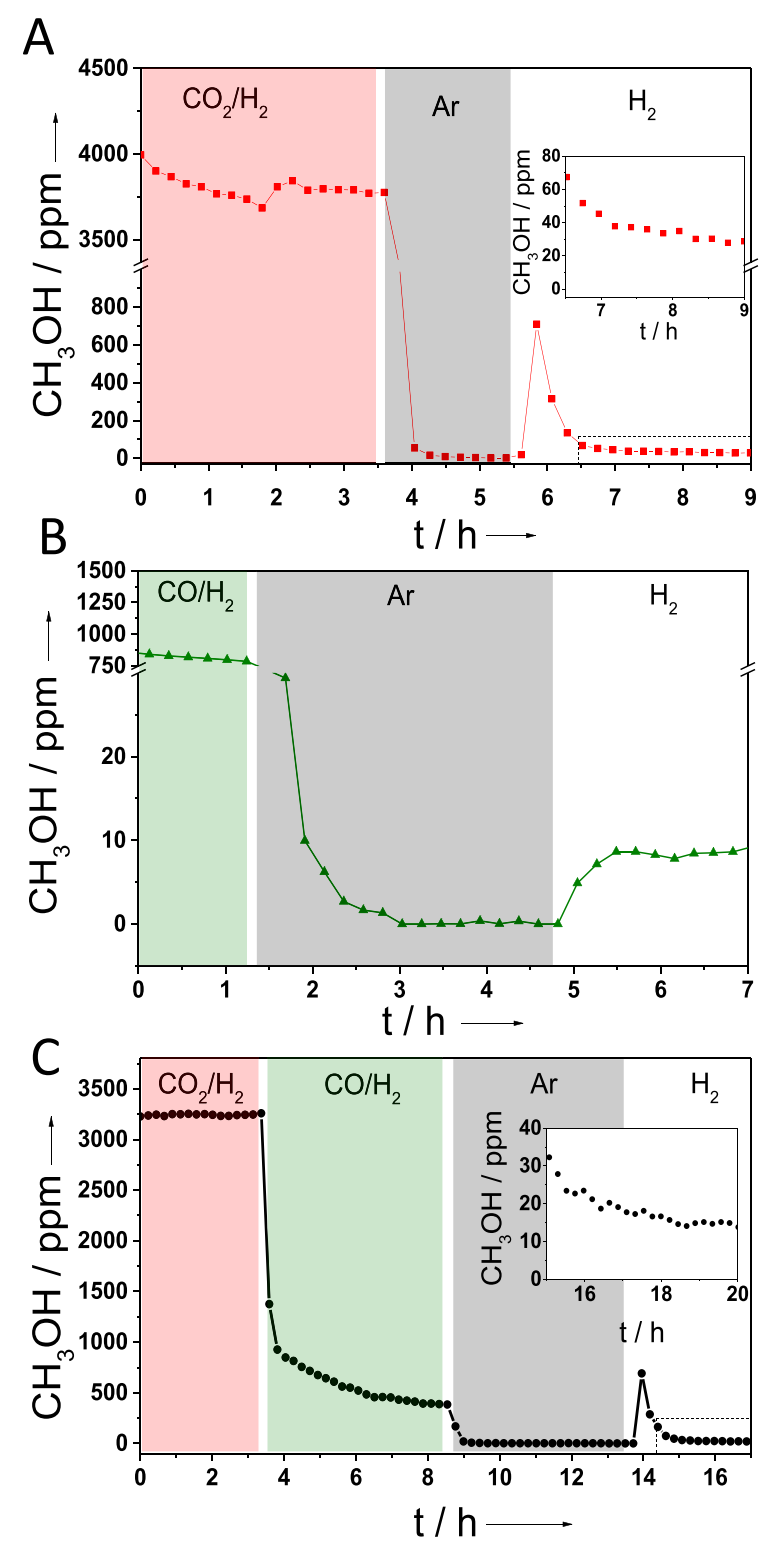

Figure 7. $\mathrm{H}_{2}$ surface titration experiments after purging with Ar from steady state at $523 \mathrm{~K}$ and 30 bar. Starting in the (A) $\mathrm{H}_{2} / \mathrm{CO}_{2}$ feed, (B) $\mathrm{H}_{2} / \mathrm{CO}$ feed, (C) $\mathrm{H}_{2} / \mathrm{CO}_{2}$ feed, and followed by the $\mathrm{H}_{2} / \mathrm{CO}$ feed.

a steady-state $\mathrm{CH}_{3} \mathrm{OH}$ concentration of $\sim 3800$ ppm is reached, and upon switching to Ar within $0.5 \mathrm{~h}$, no traces of $\mathrm{CH}_{3} \mathrm{OH}$ are detected anymore. Introducing $\mathrm{H}_{2}$ finally leads to an increase of the $\mathrm{CH}_{3} \mathrm{OH}$ concentration up to several hundred ppm. Still, after hours, low $\mathrm{CH}_{3} \mathrm{OH}$ concentrations are detected (see the inset in Figure 7A). Besides the $\mathrm{CH}_{3} \mathrm{OH}$ evolution also $\mathrm{H}_{2} \mathrm{O}$ formation is observed (Figure S7B), which is in accordance with the interpretation of the in situ thermogravimetric results (Figures 1 and 2B). Performing the identical experiment starting from a $\mathrm{H}_{2} / \mathrm{CO}$ feed (Figure $7 \mathrm{~B})$, a steady-state concentration of $\sim 800 \mathrm{ppm}$ is measured. After purging with $\mathrm{Ar}$ and switching to $\mathrm{H}_{2} / \mathrm{Ar}$, a relatively lasting increase of the $\mathrm{CH}_{3} \mathrm{OH}$ concentration to $\sim 10 \mathrm{ppm}$ is detected, and no additional $\mathrm{H}_{2} \mathrm{O}$ is detected (Figure S7B). With respect to the surface titration from the $\mathrm{H}_{2} / \mathrm{CO}_{2}$ feed, a different kinetic behavior is clearly visible (see also MS traces in Figure S7A,C). Interestingly, the carbon-derived adsorbates 
formed under $\mathrm{H}_{2} / \mathrm{CO}_{2}$ conditions stay on the surface even after introducing $\mathrm{H}_{2} / \mathrm{CO}$ for hours, made evident by an identical profile and concentration of $\mathrm{CH}_{3} \mathrm{OH}$ while titrating with $\mathrm{H}_{2} / \mathrm{Ar}$ after purging in $\mathrm{Ar}$ (Figure $7 \mathrm{C}$, Figure S7A MS signals). This is additionally supported by a lower catalytic activity in the $\mathrm{H}_{2} / \mathrm{CO}$ feed if $\mathrm{H}_{2} / \mathrm{CO}_{2}$ was applied before (Figure S9, $\mathrm{CO}_{2}$-derived intermediates block active sites). A similar purging experiment was conducted in the thermobalance (Figure S8) by switching from a $\mathrm{H}_{2} / \mathrm{CO}_{2}$ feed to $\mathrm{H}_{2} / \mathrm{CO}$ and finally purging with $\mathrm{H}_{2}$ (see also Figure 1). According to the results discussed above (Figure $2 \mathrm{~A}$ ), the surface is still covered with strongly bound $\mathrm{OH}$ groups and carbon-derived species. The introduction of $\mathrm{H}_{2}$ leads to a fast mass decrease within the first $30 \mathrm{~min}$ followed by a slow one (lasting for hours). This interpretation is in very good agreement with the results in Figure $7 \mathrm{~A}, \mathrm{C}$ and Figure $7 \mathrm{~A}, \mathrm{~B}$, where a fast $\mathrm{CH}_{3} \mathrm{OH}$ / $\mathrm{H}_{2} \mathrm{O}$ evolution occurs followed by a slow and lasting decrease. Generally, the quantity of adsorbed carbon-derived intermediates (Table 1) and the amount of $\mathrm{CH}_{3} \mathrm{OH}$ formed upon surface titration are in an acceptable agreement.

The conversion of, e.g., the methoxy groups (see also Figures $7 \mathrm{~B}$ and $4 \mathrm{~B})$ formed likely on the $\mathrm{Cu}$ sites $(400 \mu \mathrm{mol}$ $\mathrm{g}_{\text {cat }}{ }^{-1}$ ) would lead to a calculated constant formation of 10 ppm of $\mathrm{CH}_{3} \mathrm{OH}$ lasting for $20 \mathrm{~h}$. Another selected example is the $\mathrm{CH}_{3} \mathrm{OH}$ formation of $\mathrm{H}_{2} / \mathrm{CO}_{2}$-derived adsorbates (Figure 7C). Surface titration with $\mathrm{H}_{2} / \mathrm{Ar}$ leads to a calculated constant $\mathrm{CH}_{3} \mathrm{OH}$ concentration of $65 \mathrm{ppm}$ for $5 \mathrm{~h}$ (based on the available $\mathrm{Cu}$ sites of $\left.400 \mu \mathrm{mol} \mathrm{g}_{\mathrm{cat}}{ }^{-1}\right)$. Again, a reasonable agreement between the surface titration experiments (Figure 7) and the quantitative assessment from the thermobalance (Figures 1 and 3) is obtained.

\section{GENERAL DISCUSSION AND CONCLUSION}

On the basis of the results gained from high-pressure in situ thermogravimetric experiments (Figures 1-3, Table 1), the quantitative assessment of the adsorbates is in the range $\sim 1-2$ ML (monolayers) with respect to the surface titration experiments. The carbon-based ad-layer $(\sim 0.25 \mathrm{ML})$ is in fair agreement with the findings interpreted by Yang et al. and also very likely located on the $\mathrm{Cu}$ moieties. ${ }^{6 \mathrm{~b}}$ As we discussed the activated state of the catalyst under steady-state conditions, a significant amount of the surface adsorbates consist of waterderived species (at least when a $\mathrm{CO}_{2}$-containing feed is applied). Consequently, for any fundamental discussion, the role of $\mathrm{OH}$ groups and $\mathrm{H}_{2} \mathrm{O}$ has to be considered. This interpretation is confirmed by in situ high-pressure IR spectroscopy, where under realistic conditions the presence of carbon- and $\mathrm{H}_{2} \mathrm{O} / \mathrm{OH}$-derived intermediates was identified. In addition, surface titration experiments showed that the carbon-based intermediates are convertible into $\mathrm{CH}_{3} \mathrm{OH}$ upon titration with $\mathrm{H}_{2} / \mathrm{Ar}$. The oxygenates formed under the $\mathrm{CO}_{2}$ containing atmosphere seem to be quite stable, since they are still present after changing the feed gas to $\mathrm{H}_{2} / \mathrm{CO}$. Solely under $\mathrm{H}_{2} / \mathrm{CO}$ atmosphere methoxy groups are highly populated. The titration of methoxy to $\mathrm{CH}_{3} \mathrm{OH}$ is a very slow process (high reaction barriers), ${ }^{2 f, 12}$ which would explain the poor reaction rate of $\mathrm{CH}_{3} \mathrm{OH}$ in $\mathrm{H}_{2} / \mathrm{CO}(800 \mathrm{ppm}$ versus $4000 \mathrm{ppm}$ for $\mathrm{H}_{2} / \mathrm{CO}_{2}$ ) and the lasting $\mathrm{CH}_{3} \mathrm{OH}$ decrease upon titration (Figures $4 \mathrm{~B}$ and 7 ). The surface titration experiments from the $\mathrm{CO}_{2}$-based feed (Figure 7A,C, Figure S8A,B) show that the carbon-based adsorbates are convertible into $\mathrm{CH}_{3} \mathrm{OH}$ and $\mathrm{H}_{2} \mathrm{O}$. The different kinetics upon titration with respect to the $\mathrm{CH}_{3} \mathrm{OH}$ formation under the $\mathrm{H}_{2} / \mathrm{CO}$ feed suggest that another carbon intermediate is involved and that $\mathrm{H}_{2} \mathrm{O} / \mathrm{OH}$ groups are needed for its conversion (see Figure $\mathrm{S} 7 \mathrm{~B}$, no $\mathrm{H}_{2} \mathrm{O}$ evolution since $\mathrm{CO}_{2}$ free). The importance of $\mathrm{H}_{2} \mathrm{O} / \mathrm{OH}$ for the $\mathrm{CH}_{3} \mathrm{OH}$ formation was already indicated for $\mathrm{Cu}$ systems. $^{6 \mathrm{~b}, \mathrm{c}}$ Since we investigate a high-performance $\mathrm{Cu} /$ $\mathrm{ZnO}: \mathrm{Al}$, the residual strongly bound $\mathrm{OH}$ groups are located on the $\mathrm{ZnO}$ moieties of the catalyst (Figures 1 and 2). Kattel et al. ${ }^{2 f}$ already suggested the relevance of $\mathrm{OH}$ groups located on $\mathrm{ZnO}$ at the interface to $\mathrm{Cu}$. Our findings from high-pressure in situ IR, thermogravimetry, and surface titration experiments support this interpretation. In this context, the promoting role (electronic and structure $)^{14 a, 22}$ of $\mathrm{ZnO}$ has to be extended to a mechanistic one, where $\mathrm{H}_{2} \mathrm{O} / \mathrm{OH}$ groups are crucial for the activation of, e.g., formats, formyl, or carboxylates $\left(\mathrm{CO}_{2}-\right.$ derived oxygenates). To what extent the detected intermediates are part of the rate-determining step and reaction mechanism is beyond the scope of this article. The apparent activation energy of this catalyst for $\mathrm{CH}_{3} \mathrm{OH}\left(E_{\mathrm{A}}=53 \mathrm{~kJ} \mathrm{~mol}^{-1}\right.$, determined under differential conditions, Figure S10A,B) matches perfectly with the literature values. ${ }^{23}$ For $\mathrm{H}_{2} \mathrm{O}$ a comparably high value of $E_{\mathrm{A}}=75 \mathrm{~kJ} \mathrm{~mol}^{-1}$ is measured, which is interpreted as a proxy of the rWGS contribution, ${ }^{2 \mathrm{~d}}$ resulting from the $\mathrm{CO}_{2}$ hydrogenation to $\mathrm{CO}$ and/or $\mathrm{CH}_{3} \mathrm{OH}$ (Figure S10B). However, as the importance of $\mathrm{H}_{2} \mathrm{O}$ for the $\mathrm{CH}_{3} \mathrm{OH}$ formation was already made evident, we tentatively interprete the adsorption-desorption processes of accumulated $\mathrm{H}_{2} \mathrm{O}$ derived species as strongly rate influencing (activation barrier $\sim 1 \mathrm{eV})^{6 \mathrm{c}}$ and possibly defining for the lowest temperature of operation.

In summary, our results make evident the formation of a reactive ad-layer with considerable lifetimes on the surface of a high-performance $\mathrm{Cu} / \mathrm{ZnO}: \mathrm{Al}$ catalyst during and after $\mathrm{CO}_{2}$ hydrogenation. The present observations demonstrate for the first time a quantitative assessment of the catalytically formed intermediates under realistic conditions (1.9 wt \% or $1-2$ $\mathrm{ML})$. An exchange of accumulated intermediates is a process lasting for hours. This is in agreement with surface titration experiments, where, e.g., a fraction of a ML of carbon-derived intermediates is converted with $\mathrm{H}_{2}$ within hours. $\mathrm{H}_{2} \mathrm{O}$-derived species play a crucial role within the reaction network as intermediates, reaction participants, and possibly rate-determining reactants. Further, the accumulation of $\mathrm{H}_{2} \mathrm{O}$ on $\mathrm{Cu}$ / $\mathrm{ZnO}$ catalysts might also be one reason for its limited applicability at milder temperatures (thermodynamically more favored conditions). The combined approach of in situ thermogravimetry (quantitative), in situ IR spectroscopy (qualitative), and surface titration experiments enabled the identification of another promoting effect of $\mathrm{ZnO}$, since the $\mathrm{CO}_{2}$-derived reaction intermediates are only activated when $\mathrm{Zn}-\mathrm{OH}$ is present. Our experimental data and their corresponding interpretation are in very good agreement with the literature and further clarify some ambiguities since investigations were performed on a real $\mathrm{Cu} / \mathrm{ZnO}: \mathrm{Al}$ catalyst under meaningful conditions. The current work may be considered as an example of the development and implementation of a new diagnostic tool based on a wellestablished method, providing highly relevant in situ data for a reliable mechanistic/kinetic discussion and modeling in the future. 


\section{ASSOCIATED CONTENT}

\section{S Supporting Information}

The Supporting Information is available free of charge on the ACS Publications website at DOI: 10.1021/acscatal.9b01241.

Experimental section and additional data and figures including reference measurements, thermobalance experiments, impact of the $p\left(\mathrm{H}_{2} \mathrm{O}\right)$, IR reference experiments, surface titration experiments, and catalytic data (PDF)

\section{AUTHOR INFORMATION}

\section{Corresponding Authors}

*E-mail: tarasov@fhi-berlin.mpg.de.

*E-mail: efrei@fhi-berlin.mpg.de.

\section{ORCID $\odot$}

Elias Frei: 0000-0003-3565-1199

\section{Notes}

The authors declare no competing financial interest.

\section{ACKNOWLEDGMENTS}

The authors express their gratitude to Edward Kunkes for scientific and technical assistance by developing the method and to Malte Behrens for continuous support and fruitful discussions. Elisabeth Wolf is cordially acknowledged for linguistic assistance and Julia Schumann for synthesizing. A.V.T. sincerely thanks Nygil Thomas for the long reactivity test, help with TG experiments, and daily discussions.

\section{REFERENCES}

(1) (a) Schlögl, R., Ed. Chemical Energy Storage; Walter de Gruyter GmbH, 2012. (b) Olah, G. A.; Goeppert, A., Surya Prakash, G. K. Beyond Oil and Gas: The Methanol Economy; WILEY-VCH, 2011.

(2) (a) Álvarez Galván, C.; Schumann, J.; Behrens, M.; Fierro, J. L. G.; Schlögl, R.; Frei, E. Reverse water-gas shift reaction at the $\mathrm{Cu} /$ $\mathrm{ZnO}$ interface: Influence of the $\mathrm{Cu} / \mathrm{Zn}$ ratio on structure-activity correlations. Appl. Catal., B 2016, 195, 104-111. (b) Lunkenbein, T.; Girgsdies, F.; Kandemir, T.; Thomas, N.; Behrens, M.; Schlögl, R.; Frei, E. Bridging the Time Gap: A Copper/Zinc Oxide/Aluminum Oxide Catalyst for Methanol Synthesis Studied under Industrially Relevant Conditions and Time Scales. Angew. Chem. 2016, 128 (41), 12900-12904. (c) Frei, E.; Gaur, A.; Lichtenberg, H.; Heine, C.; Friedrich, M.; Greiner, M.; Lunkenbein, T.; Grunwaldt, J.-D.; Schlögl, R. Activating a $\mathrm{Cu} / \mathrm{ZnO}: \mathrm{Al}$ Catalyst - Much More than Reduction: Decomposition, Self-Doping and Polymorphism. ChemCatChem 2019, 11 (6), 1587-1592. (d) Zwiener, L.; Girgsdies, F.; Brennecke, D.; Teschner, D.; Machoke, A. G. F.; Schlögl, R.; Frei, E. Evolution of zincian malachite synthesis by low temperature coprecipitation and its catalytic impact on the methanol synthesis. Appl. Catal., B 2019, 249, 218-226. (e) Senanayake, S. D.; Ramírez, P. J.; Waluyo, I.; Kundu, S.; Mudiyanselage, K.; Liu, Z.; Liu, Z.; Axnanda, S.; Stacchiola, D. J.; Evans, J.; Rodriguez, J. A. Hydrogenation of $\mathrm{CO}_{2}$ to Methanol on $\mathrm{CeOx} / \mathrm{Cu}(111)$ and $\mathrm{ZnO} / \mathrm{Cu}(111)$ Catalysts: Role of the Metal-Oxide Interface and Importance of $\mathrm{Ce}^{3+}$ Sites. J. Phys. Chem. C 2016, 120 (3), 1778-1784. (f) Kattel, S.; Ramírez, P. J.; Chen, J. G.; Rodriguez, J. A.; Liu, P. Active sites for $\mathrm{CO}_{2}$ hydrogenation to methanol on $\mathrm{Cu} / \mathrm{ZnO}$ catalysts. Science 2017, 355 (6331), 1296-1299.

(3) (a) Studt, F.; Behrens, M.; Kunkes, E. L.; Thomas, N.; Zander, S.; Tarasov, A.; Schumann, J.; Frei, E.; Varley, J. B.; Abild-Pedersen, F.; Nørskov, J. K.; Schlögl, R. The Mechanism of $\mathrm{CO}$ and $\mathrm{CO}_{2}$ Hydrogenation to Methanol over Cu-Based Catalysts. ChemCatChem 2015, 7 (7), 1105-1111. (b) Kobl, K.; Angelo, L.; Zimmermann, Y.; Sall, S.; Parkhomenko, K.; Roger, A.-C. In situ infrared study of formate reactivity on water-gas shift and methanol synthesis catalysts. C. R. Chim. 2015, 18 (3), 302-314.

(4) (a) Yoshihara, J.; Campbell, C. T. Methanol Synthesis and Reverse Water-Gas Shift Kinetics over $\mathrm{Cu}(110)$ Model Catalysts: Structural Sensitivity. J. Catal. 1996, 161 (2), 776-782. (b) Hansen, J. B.; Nielsen, P. E. H. Methanol Synthesis. In Handbook of Heterogeneous Catalysis, 2nd, Completly Revised and Enlarged ed.; Ertl, G., Knötzinger, H., Schüth, F., Weitkamp, J., Eds.; WILEY-VCH Verlag GmbH \& Co. KGaA: Weinheim, 2008; Vol. 6, pp 2920-2949. (c) Waugh, K. C. Methanol Synthesis. Catal. Today 1992, 15 (1), 51-75. (d) Saussey, J.; Lavalley, J. C. An in situ FT-IR study of adsorbed species on a $\mathrm{Cu}-\mathrm{ZnAl}_{2} \mathrm{O}_{4}$ methanol catalyst under $1 \mathrm{MPa}$ pressure and at $525 \mathrm{~K}$ : effect of the $\mathrm{H}_{2} / \mathrm{CO} / \mathrm{CO}_{2}$ feed stream composition. J. Mol. Catal. 1989, 50 (3), 343-353.

(5) (a) Klier, K. Methanol Synthesis. In Advances in Catalysis; Eley, D., Pines, H., Weisz, P., Eds.; Academic Press, 1982; Vol. 31, pp 243313. (b) Fujita, S.-i.; Usui, M.; Ohara, E.; Takezawa, N. Methanol synthesis from carbon dioxide at atmospheric pressure over $\mathrm{Cu} / \mathrm{ZnO}$ catalyst. Role of methoxide species formed on $\mathrm{ZnO}$ support. Catal. Lett. 1992, 13 (4), 349-358.

(6) (a) Yang, Y.; Mei, D.; Peden, C. H. F.; Campbell, C. T.; Mims, C. A. Surface-Bound Intermediates in Low-Temperature Methanol Synthesis on Copper: Participants and Spectators. ACS Catal. 2015, 5 (12), 7328-7337. (b) Yang, Y.; Mims, C. A.; Mei, D. H.; Peden, C. H. F.; Campbell, C. T. Mechanistic studies of methanol synthesis over $\mathrm{Cu}$ from $\mathrm{CO} / \mathrm{CO}_{2} / \mathrm{H}_{2} / \mathrm{H}_{2} \mathrm{O}$ mixtures: The source of $\mathrm{C}$ in methanol and the role of water. J. Catal. 2013, 298, 10-17. (c) Zhao, Y.-F.; Yang, Y.; Mims, C.; Peden, C. H. F.; Li, J.; Mei, D. Insight into methanol synthesis from $\mathrm{CO}_{2}$ hydrogenation on $\mathrm{Cu}(111)$ : Complex reaction network and the effects of $\mathrm{H}_{2} \mathrm{O}$. J. Catal. 2011, 281 (2), 199-211.

(7) Edwards, J. F.; Schrader, G. L. In situ fourier transform infrared study of methanol synthesis on mixed metal oxide catalysts. J. Catal. 1985, 94 (1), 175-186.

(8) Fisher, I. A.; Bel, A. T. In-Situ Infrared Study of Methanol Synthesis from $\mathrm{H}_{2} / \mathrm{CO}_{2}$ over $\mathrm{Cu} / \mathrm{SiO} 2$ and $\mathrm{Cu} / \mathrm{ZrO}_{2} / \mathrm{SiO}_{2}$. J. Catal. 1997, 172, 222-237.

(9) Yang, Y.; Mims, C. A.; Disselkamp, R. S.; Peden, C. H. F.; Campbell, C. T. Simultaneous MS-IR Studies of Surface Formate Reactivity Under Methanol Synthesis Conditions on $\mathrm{Cu} / \mathrm{SiO}_{2}$. Top. Catal. 2009, 52 (10), 1440-1447.

(10) (a) Sahibzada, M.; Metcalfe, I. S.; Chadwick, D. Methanol Synthesis from $\mathrm{CO} / \mathrm{CO}_{2} / \mathrm{H}_{2}$ over $\mathrm{Cu} / \mathrm{ZnO} / \mathrm{Al}_{2} \mathrm{O}_{3}$ at differential and finite conversions. J. Catal. 1998, 174, 111-118. (b) Martin, O.; Pérez-Ramírez, J. New and revisited insights into the promotion of methanol synthesis catalysts by $\mathrm{CO}_{2}$. Catal. Sci. Technol. 2013, 3 (12), 3343.

(11) Wu, P.; Yang, B. Significance of Surface Formate Coverage on the Reaction Kinetics of Methanol Synthesis from $\mathrm{CO}_{2}$ Hydrogenation over $\mathrm{Cu}$. ACS Catal. 2017, 7 (10), 7187-7195.

(12) Grabow, L. C.; Mavrikakis, M. Mechanism of Methanol Synthesis on $\mathrm{Cu}$ through $\mathrm{CO}_{2}$ and $\mathrm{CO}$ Hydrogenation. ACS Catal. 2011, 1 (4), 365-384.

(13) Kandemir, T.; Friedrich, M.; Parker, S. F.; Studt, F.; Lennon, D.; Schlogl, R.; Behrens, M. Different routes to methanol: inelastic neutron scattering spectroscopy of adsorbates on supported copper catalysts. Phys. Chem. Chem. Phys. 2016, 18 (26), 17253-17258.

(14) (a) Schumann, J.; Eichelbaum, M.; Lunkenbein, T.; Thomas, N.; Álvarez Galván, M. C.; Schlögl, R.; Behrens, M. Promoting Strong Metal Support Interaction: Doping $\mathrm{ZnO}$ for Enhanced Activity of $\mathrm{Cu} / \mathrm{ZnO}: \mathrm{M}(\mathrm{M}=\mathrm{Al}, \mathrm{Ga}, \mathrm{Mg})$ Catalysts. ACS Catal. 2015, 5 (6), 3260-3270. Kuld, S.; Conradsen, C.; Moses, P. G.; Chorkendorff, I.; Sehested, J. Quantification of Zinc Atoms in a Surface Alloy on Copper in an Industrial-Type Methanol Synthesis Catalyst. Angew. Chem. 2014, 126, 6051.

(15) Lunkenbein, T.; Schumann, J.; Behrens, M.; Schlögl, R.; Willinger, M. G. Formation of a $\mathrm{ZnO}$ overlayer in industrial $\mathrm{Cu}$ / $\mathrm{ZnO} / \mathrm{Al}_{2} \mathrm{O}_{3}$ catalysts induced by strong metal-support interactions. Angew. Chem., Int. Ed. 2015, 54 (15), 4544-8. 
(16) Arakawa, H.; Fukushima, T.; Ichikawa, M. Novel High-Pressure FT-IR Spectroscopic System Combined with Specially Designed In Situ IR Cell for Studying Heterogeneous Catalytic Reactions. Appl. Spectrosc. 1986, 40 (6), 884-886.

(17) (a) Le Peltier, F.; Chaumette, P.; Saussey, J.; Bettahar, M. M.; Lavalley, J. C. In situ FT-IR and kinetic study of methanol synthesis from $\mathrm{CO}_{2} / \mathrm{H}_{2}$ over $\mathrm{ZnAl}_{2} \mathrm{O}_{4}$ and $\mathrm{Cu}-\mathrm{ZnAl}_{2} \mathrm{O} 4$ catalysts. J. Mol. Catal. A: Chem. 1998, 132 (1), 91-100. (b) Edwards, J. F.; Schrader, G. L. Infrared spectroscopy of copper/zinc oxide catalysts for the water-gas shift reaction and methanol synthesis. J. Phys. Chem. 1984, 88 (23), $5620-5624$.

(18) Ryazantsev, S. V.; Tyurin, D. A.; Feldman, V. I. Experimental determination of the absolute infrared absorption intensities of formyl radical HCO. Spectrochim. Acta, Part A 2017, 187, 39-42.

(19) Karelovic, A.; Galdames, G.; Medina, J. C.; Yévenes, C.; Barra, Y.; Jiménez, R. Mechanism and structure sensitivity of methanol synthesis from $\mathrm{CO}_{2}$ over $\mathrm{SiO}_{2}$-supported $\mathrm{Cu}$ nanoparticles. J. Catal. 2019, 369, 415-426.

(20) Schilke, T. C.; Fisher, I. A.; Bell, A. T. In SituInfrared Study of Methanol Synthesis from $\mathrm{CO}_{2} / \mathrm{H}_{2}$ on Titania and Zirconia Promoted $\mathrm{Cu} / \mathrm{SiO}_{2}$. J. Catal. 1999, 184 (1), 144-156.

(21) Yang, Y.; Mims, C. A.; Disselkamp, R. S.; Kwak, J.-H.; Peden, C. H. F.; Campbell, C. T. (Non)formation of Methanol by Direct Hydrogenation of Formate on Copper Catalysts. J. Phys. Chem. C 2010, 114 (40), 17205-17211.

(22) Behrens, M. Promoting the Synthesis of Methanol: Understanding the Requirements for an Industrial Catalyst for the Conversion of $\mathrm{CO}_{2}$. Angew. Chem., Int. Ed. 2016, 55 (48), 1490614908.

(23) Schumann, J.; Lunkenbein, T.; Tarasov, A.; Thomas, N.; Schlögl, R.; Behrens, M. Synthesis and Characterisation of a Highly Active $\mathrm{Cu} / \mathrm{ZnO}: \mathrm{Al}$ Catalyst. ChemCatChem 2014, 6, 2889-2897. 